\title{
UNIVERSITYOF
}

FORWARD

THINKING

WESTMINSTER用

WestminsterResearch

http://www.westminster.ac.uk/westminsterresearch

The PTA: Promoting Swiss Tours, 1888-1939

Dominici, S. and Maitland, R.

NOTICE: this is the authors' version of a work that was accepted for publication in Annals of Tourism Research. Changes resulting from the publishing process, such as peer review, editing, corrections, structural formatting, and other quality control mechanisms may not be reflected in this document. Changes may have been made to this work since it was submitted for publication. A definitive version was subsequently published in Annals of Tourism Research.

The definitive version in Annals of Tourism Research is available online at:

https://dx.doi.org/10.1016/j.annals.2016.05.010

(c) 2016. This manuscript version is made available under the CC-BY-NC-ND 4.0 license http://creativecommons.org/licenses/by-nc-nd/4.0/

The WestminsterResearch online digital archive at the University of Westminster aims to make the research output of the University available to a wider audience. Copyright and Moral Rights remain with the authors and/or copyright owners.

Whilst further distribution of specific materials from within this archive is forbidden, you may freely distribute the URL of WestminsterResearch: (http://westminsterresearch.wmin.ac.uk/)).

In case of abuse or copyright appearing without permission e-mail repository@westminster.ac.uk 
THE PTA: PROMOTING SWISS TOURS, 1888-1939

\begin{abstract}
This research examines the development from educational to commercial tourism in Britain between the late-nineteenth and early-twentieth century by questioning whether this reflected a transformed understanding of the role of travel within society. It focuses on the Polytechnic Touring Association (PTA), a London-based originally philanthropic travel organisation that became a commercial firm. During this period the PTA moved from the project of contributing to the education of citizens to the market-led imperative of 'harnessing' a consumer desire. In examining this transformation via the PTA's changing approach to the visual promotion of its Swiss tours, we suggest that the development of the tourism industry in Britain should also be explored in relation to changing ideas about travel's contribution to social formation.
\end{abstract}

Keywords: Polytechnic Touring Association, education, consumerism, representation, identity, tourism

\title{
INTRODUCTION
}

While the literature on the emergence of modern British tourism has explored the negotiation between the original educational ambition of some of the early travel firms and the pressing demands of an increasingly competitive market, substantially less has been written about how this transformation might also have been influenced by changing perceptions of the benefits of travel. This is possibly due to the richness and complexity of the field (Ritchie et al., 2003), but perhaps also because Western cultures see education as mainly 'work' and travel as mainly 'pleasure' (Werry, 2008). Consequently, although studies do recognise how learning can take place beyond formal education (Broomhall et al., 2010; Shennan, 1991; Watson, 2003) including through travel itself (Werry, 2008) - the relationship between travel and learning is still a largely neglected area (Falk et al., 2012).

We contribute to this discussion by examining the changing expectations of travel developed within the Polytechnic Touring Association (PTA). The PTA originated at the end of the nineteenth century within the Regent Street Polytechnic, London (henceforth the Polytechnic), which became the University of Westminster in 1992. Its origins were as a philanthropic organisation but it became a commercial travel 
company. Exploring its development allows a magnified analysis of widespread social changes in the approach to travel. Emerging from an educational context, and maintaining a connection with its parent institution, the PTA provides a particularly rich and productive case to investigate how the education-based framework of the early tours was re-negotiated as the mass marketing of tourism developed. In order to discuss this transition the focus here is on the years between 1888 and 1939, after which the PTA links with the Polytechnic weakened considerably, and on the PTA's promotional representation of its tours to Switzerland, which changed profoundly during this period. By using a combination of historical and visual methods, this research interrogates how far changes in visual marketing reveal the reconceptualisation of the initial idea of tourism as personal development. In doing so, it contributes to understanding the changing (expected) social role of tourism in the early years of the twentieth century. The legacy of the PTA was long lasting: having changed its name to Poly Travel in 1958, it became part of the group later named Lunn Poly in 1962. This underlines the complex origins of British outbound tourism, generally discussed in relation to commercial firms such as Thomas Cook, drawing attention to the largely unexplored role that early educational ambitions had in its growth and development.

\section{SOURCES AND METHODOLOGIES}

The analysis of the PTA presented in this research draws on a thorough examination of the documents relating to the Polytechnic and to the PTA, held at the University of Westminster Archive in London. These include administrative and financial records; publications (i.e. tour brochures, guidebooks, leaflets, posters and postcards); programmes of tour reunions; memorabilia; photographs, glass slides and cinematographic films (see Dominici, 2014, 2015 for further exploration of the archive material). In order to investigate the changing discourse of 'education' and travel we focus on the visual and printed material produced by the travel company looking in particular at the promotion of Switzerland during the period 1888-1939. The Swiss tours were the flagship of the PTA offer, thus allowing for a fruitful longitudinal study of the changing promotional image of the country. The Swiss focus reflected the popularity of the destination at this time (Barton, 2008; Ring, 2011) and the company's invested interest in chalets and hotels it purchased in Lucerne in 1894, Grindelwald in 1923, and Interlaken in 1939 (PM, January, 1939, p. 6; Studd, 1950, p. 119-121). Little information remains about exactly who commissioned and produced this promotional material. Archive documents suggest that in the period from 1888 to 1923 it was the Polytechnic's senior management, whilst from 1924 
external advertising companies were also involved. This indicates the progressive professionalisation of the task of promoting the tours as the organisation moved from education to commerce. The images produced by the PTA are thus discussed in the context of its changing approaches to travel, seeking to understand the visual articulation of the experience of travelling in relation to its expected contribution to social formation. Specifically, we question the development of the visual commodification of travel destinations not just as products of consumption, but also in relation to a transformed understanding of the relationship between travel and how this was seen to shape social identities. In order to interpret the PTA's printed material and thus advance our understanding of tourism, we draw from a combination of discourse analysis, routinely used within tourism studies to interrogate texts (Hannam \& Knox, 2005), and photographic analysis, which examines images as historical processes (Barthes, 1977). As Barthes influentially demonstrated (1977), visual analysis of photographic images must account for two levels of interpretation of an image: denotation (a descriptive level of what the image obviously shows) and connotation (interpretation in terms of wider ideology). This is a familiar and successful way of interpreting photographic images (see for example Sekula, 1986; Tagg, 1988) that builds on discourse analysis, which is instead concerned with texts. In order to demonstrate that archive documents can also be analysed at the intersection of discourse and visual analysis we extend Tribe's method of 'virtual curating', which proposes approaching representations "as a text to be interrogated like other texts" (2008, p. 925), to the analysis of visual and printed archive sources. While Tribe focuses on artworks, we argue that the "intermingling [of] text and image" (2008, p. 941) that he proposes can be adapted to the analysis of destination marketing. That is, "virtual curating" allows us to interpret both visual and text materials by focusing on the 'attitudes' that produced certain material, and whose analysis goes beyond the restrictions imposed by what can be read (in a text) or seen (in an image). We do so by analysing the 'intermingling' of the content and description of the images produced by the PTA in relation to a contextual historical analysis of the socio-cultural forces that defined the period under investigation.

By interrogating the archive's holdings as the official 'manifesto' of the PTA, as it developed from the nineteenth century, it is thus possible to explore how the organisation saw itself, its objectives and its audience, as well as broader shifts in the understanding of tourism in this period. Whilst not all the material produced by the PTA has survived, the University of Westminster Archive holds an extensive and diverse selection of documents. This means that the engagement with the archive 
must aim not to map out the PTA's total production of promotional material, but to investigate how its choices, specifically in the promotion of Switzerland, reflected a particular discourse of travel as personal development.

This is a line of enquiry that, acknowledging Tribe's call for a more reflexive research approach in tourism $(2005,2006)$, focuses on the PTA as a revealing case study through which to explore issues relating to the development and changing relationship between the British tourism industry, education and leisure. In doing so we draw attention to the use of archival documents in tourism research, which has been largely underexplored. Already in 1988, building on Pimlot's pioneering work (1947), Towner suggested that "archive research on firms engaged in the tourism industry may reveal new sources of information" (1988, p. 56). This has since contributed to further understandings of the development of modern British travel firms (for example Snape, 2004), yet has broadly sought to "reconstruct the reality of a particular past period or event" rather than "develop more general concepts of society where the specific historicity of the data is not of central importance" (Towner, 1988, p. 51). As a result, "at present the influence of a few travel firms has perhaps been overstressed" (Towner, 1988, p. 56; Walton, 2009), for example in the case of the many histories of Thomas Cook (see for example Swinglehurst, 1982). The PTA itself has received little coverage in the secondary literature on the history of British tourism (Matthews, 2013; Strong, 2012, 2014), and this primarily focuses on the specific case of the PTA rather than exploring social developments more broadly. Conversely, the research and methodology adopted within this paper seek to relate the "specific historicity of the data" concerning the PTA to a broader understanding of the role of tourism within society. By focusing on an exemplary analysis of the PTA's promotion of its Swiss tours, we bring a novel perspective to the changing perceptions of the benefits of travel in the late-nineteenth and earlytwentieth century.

\section{CHANGING PERCEPTIONS OF THE BENEFITS OF TRAVEL}

Research on the development of ideas on the improving (educational) effects of travelling has focused on the legacy of the Grand Tour (Adler, 1989; Dent, 1975; Towner, 1985) and of the tramping tradition (Adler, 1985; Borocz, 1992), and explored the transformation of these traditions in the context of travel as 'rational recreation' in the nineteenth century (Bailey, 1978), and of the emergence of an approach to culture as consumable experience in the twentieth century (for example Dicks, 2003; Richards, 1996; Walsh, 1992). These studies indicate how, throughout 
this period, the 'consumption' of culture moved from initially espoused educational to increasingly hedonistic purposes, this within an emerging competitive travel market (for example Baywater, 1993; Syrjämaa, 2008). The shift was accompanied by a parallel decrease in the cultural dimension of the more general travel experience, while the motives declared by the tourists for travelling thereby progressively moved towards non-cultural ones (Baywater, 1993; Craik, 1997). Cultural commodification has thus increasingly contributed to the formation of the tourist experience (Ateljevic \& Doorne, 2003; Urry, 1990; Watson \& Kopachevsky, 1994) which is seen as both creating and responding to an increasingly individualised and consumerist society (Franklin, 2007; Shepherd, 2002). Far from suggesting that nineteenth century forms of travel were only sought for educational opportunities, or that later experiences were solely in pursuit of pleasure, these studies nonetheless indicate that the relationship between the cultural meaning of travel and its social identity has changed in parallel with an expanding consumer culture. On this account, we argue that the changing perceptions and expectations of the benefits of travelling can be investigated in relation to the commodification of culture.

Specifically, drawing from studies on the modern concept of leisure (for example Adorno, [1969] 1991; Burke, 1995), we argue that the roots of the development of the concept of cultural travel must be considered in relation to that "great divide between pre-industrial and industrial society" in which the development of an idea of leisure has been located (Burke, 1995, p. 137). The concept of leisure as distinct to that of work, Burke argues, is modern not because before the Industrial Revolution people did not enjoy free time, but because only as a result of its organisation and institutionalisation did "people became more conscious of it as a separate domain" (1995, p. 149). The perception of culture that developed in industrial society - and, in turn, its relationship with the idea of travel - can be understood along similar lines. That is, the proposition that cultural travel only developed in the nineteenth century does not imply that previous travel formats were lacking in cultural terms, but that it was the social and cultural contexts specific to this period that recognised the cultural dimension of travel as an element to be consumed. According to this perspective, cultural tourism developed as a devalued and subordinated form of travel. This holds that commodification results in a fundamental loss of 'authentic' experience - hence MacCannell's argument that what tourists seek, in compensation, is authenticity itself (1976). The role allocated to culture within a consumer society itself has experienced a number of changes: from being understood as an intrinsic part of the experience of travel in general, since the mid-1980s culture has increasingly been brought to the 
fore as a commodity to purchase and consume in itself, transformed into "commercial value" (Lanfant, 1995, p. 37). A growing body of research has been complicating this view, exploring the active role that individuals play in the consumption of culture (see for example Bagnall, 1996; Breathnach, 2006). To what extent individual demands and concerns might have influenced the development of the British tourism industry, however, is largely unexplored.

Therefore, the view of tourism as a devalued leisure activity, the literature's recognition of a shift in motivations for and approaches to travelling, and the emergence of an approach to culture as a commodity, can be problematised by accounting for the circumstances within which the Polytechnic, and then the PTA, intended to operate. We explore this, via an analysis of the PTA's changing approach to the visual promotion of the Swiss tours, by questioning to what extent the PTA's intentions were driven by, or reflected, the wider social changes discussed so far. This will further our understanding of the changing intertwined discourses of travel, culture and leisure in the early years of the twentieth century.

\section{THE POLYTECHNIC TOURING ASSOCIATION, 1888-1939}

The PTA, whose first official foreign tour, to Switzerland, took place in 1888 , owed its conception to its links with the Polytechnic. The personal project of the philanthropist and businessman Quintin Hogg (1845-1903), the Polytechnic had opened in 1882 at 309 Regent Street, London, with the aim, as reported by the in-house journal, the Polytechnic Magazine ( $P M)$, "to make a man into a good citizen, by helping him educationally, physically, socially, and helping him to a true religion" (October, 1913, p. 175). Hogg had a privileged upbringing (his father was a successful lawyer, MP and later a director of the East India Company), was an outspoken evangelist, and had numerous business interests (particularly in the sugar plantations in Demerara). These elements gave him the means, and a vision, to pursue his project: turn the Polytechnic into "not only one of the great centres of Christian effort, but also a centre of education for the artisans of this great city" (Home Tidings, March 1882, p. 42). Developing in a largely nationalistic and imperialistic context, when Britain felt that new powerful states were challenging its industrial and global hegemony (Musgrave, 1964), Hogg's project sought to equip the Polytechnic's members with educational skills and moral values that would help them to find a (working) place in society. This was an attempt to respond actively to the challenges faced by the 'lower' classes within a changing society - a time during which concerns with the cultural welfare of the population, against a backdrop of new political and class 
interests, gave education an important social role (Barton, 2005; Cordery, 1995; MacKenzie, 2001; Thompson, 1988). In the effort to form modern citizens, Hogg developed a progressive curriculum of technical classes, aimed at young working people (Heller, 2013). Travel was considered a complementary aspect of this project, and was supported through subject-specific excursions organised with the Polytechnic schools and societies, emigration and work-experiences abroad. As Strong has argued, drawing from MacCannell's seminal study of leisure travel (1976), modern educational travel was "a cultural response to working-class demands for inclusion in the nation, and middle-class attempts to contain them" (2014, p. 3). The Polytechnic travel arrangements conformed to that broader "basically and relentlessly didactic" (Bailey, 1978, p. 47) structuring of social activities, which aimed at regulating working-class leisure within dominant middleclass ideology (Bennett, 1988; Huggins \& Mangan, 2004; Morgan \& Pritchard, 1998), by encouraging adherence to 'rational recreation', self-improvement and respectability. The success of Hogg's project was such that in 1891 the Government's Charity Commissioners started supporting the Polytechnic financially. This sanctioned the separation between educational, and social and recreational activities, and determined the fate of the Polytechnic's travel arrangements. The Polytechnic consequently opened to the broad middle class market and in 1911, established as a company limited by shares, the PTA became a commercial body. The links with its parent institution, however, remained; for example until the end of the 1930 s it donated up to $£ 3,000$ annually to the Polytechnic. The PTA was successful commercially, and bookings to Switzerland soared from around 2,500 in 1894, to 8,500 in 1902. By 1905 the Polytechnic Holiday Tours Programme announced there had been 13,000 tourists in the previous year and Ethel Wood, Hogg's daughter, estimated that by 1914 the PTA was catering for more than 16,000 per year (1934, p. 35).

Despite the early turn towards commerce, in the period from its origins in the late nineteenth century, to the years immediately following the First World War, the ambition of the tours remained that of forming a modern, national and imperial, citizenship. A discourse of pride in the achievements of the British Empire, present in people's everyday lives (Thompson, 2005; Hall \& Rose, 2006), and of the issue of its citizens' role within, was central during this period to the work of Hogg's Polytechnic and other bodies, which thus helped establishing a "nationalized citizenry" (Bennett, 1988, p. 80) and an imperial identity (Morgan, 2001; Thorne, 1999). Accordingly, numerous organisations ran tours structured around educational and social 
concerns. For example the Co-operative Holidays Association (1891), and its Holidays Fellowship (1913); Toynbee Hall, with the Children's Country Holiday Fund and the Toynbee Travellers' Club (eventually the Workmen's Travelling Hall); the tours arranged by Henry Lunn, Dean and Dawson, and John Frame (Pimlott, 1947); and those organised by Mechanic's Institutes and Friendly Societies in the north of England (Barton, 2005). In the emerging PTA, this approach was reinforced by the commitment to education and travel of Hogg's close collaborator Robert Mitchell (1855-1933), who managed the tours until retirement in 1923. Mitchell had started working with Hogg in 1871 as honorary Secretary of the Young Men's Christian Institute, an earlier incarnation of the Polytechnic, before becoming the Polytechnic's Director of Education in 1891. His vision was hence closely aligned with broader latenineteenth century concerns with popular education, and supported by the fact that many Polytechnic teachers doubled as tour guides. In practice, motives for travelling with the PTA were diverse and, commercial imperatives became increasingly important (as archive documents reveal, Dominici 2014). Yet, the ambition to act as an 'educator' still determined the organisation's self-perception: preoccupied, as it put it in 1923, with "the wider outlook of the intrinsic value of the service to its beneficiaries" (PM, December, 1923, p. 221).

In 1924 after thirty-six years at the head of the PTA, Mitchell retired. J.E.K. Studd, since 1911 Chairman and part owner (with Mitchell and Hogg's son Douglas) of the PTA, and by then also President of the Polytechnic, appointed his son Ronald Studd (1889-1956) as the new Managing Director. With Studd a new phase began, crucially affected by the socio-cultural and economic transformations that had followed the First World War. The passage to the interwar years was perceived not as a transition but as a fracture with the previous social order: the war had changed profoundly how people understood the world and their place in it (Fussell, 1980; Hobsbawm, 1975), and facilitated a progress in mobility, technology and communication systems (see for example Middleton \& Lickorish, 2005). This affected the attitude towards travel, further shaped by gradual increases in holiday time and disposable income: this influenced the format of the journey, expectations and demands of travel, and what the emerging tourism industry could offer (Graves \& Hodge, 1991; Jones, 1986; Walton \& Walvin, 1983). Consequently, the discourse of travel changed in the public consciousness. A leisure approach to holidaying had long defined the experience of seaside visitors (Walvin, 1978; Walton 2000), or of those who participated in organised excursions (Barton, 2005; Redfern, 1983) in the second half of the nineteenth century - although often under the claim of health benefits and self- 
improvement. This now extended to embrace the idea that travelling abroad, up to this point broadly perceived as an opportunity to add to one's cultural capital in pursuit of respectability (Bourdieu, 1984, 1986; Simon, 1974), should also entail "healthy, free and mobile leisure" (Inglis, 2000, p. 111). Aware of these transformations, Studd made it his mission to bring the company in line with the industry, starting structural transformations as soon as he took control of the company. He appointed a General Manager in charge of administering the office work; set up a Plan Division with the task of developing a distinct image for the PTA and a new advertising campaign; and employed a staff manager and new staff from outside the Polytechnic. The relationship with tourists was also transformed, as Studd made catering for tourists' desires the principal aim of the PTA, now presented as a 'service provider'.

Studd, as Mitchell before him, was a charismatic figure, key to the development of the PTA, so much so that he eventually became the personification of the PTA itself (see for example figure 5). Yet, in both cases personalities should not be seen as the cause behind the PTA's changing attitudes; rather, their choices reflected the wider forces, introduced in this section, within which they operated. Studd recognised that the PTA could survive in a competitive market only by revamping. In 1929 he bought out Mitchell's shares, and Mitchell ended his involvement - both legally and in terms of the influence he had had on the PTA's formation. Although there are no remaining accounts of the PTA's finances in this period, indications of the company's activities and continuing success are provided by the fact that between 1925 and 1930 the firm was estimated to have increased bookings from 15,000 to over 29,000 (Studd, 1950: 143), and that the mortgage taken in 1923 to buy two hotels in Grindelwald had been repaid by 1931 . The company's acquisition by Lunn Poly in 1962 also suggests that it was seen as a worthy asset: Studd certainly managed, as he later recalled, "to move higher into the class of "formidable rivals"' (1950, p. 139).

\section{FORMING MODERN AND RESPECTABLE CITIZENS, 1888 - 1923}

In June 1890, preceding the beginning of the summer season, the PM allocated 16 pages to a new section titled Poly Members at Play - Holiday Tours and Holiday Homes, 1890. This was the first attempt at presenting in an organised form the Polytechnic's growing offer of tours, which starting in 1892 was published as a separate brochure. Printed before the Polytechnic had officially opened its tours to non-members, when the ambition of providing educational tours had not yet had to compromise with external demands, the richly illustrated insert (it contained 44 
images) presented a view of the world that, we can presume, conformed with the organisation's didactic objectives. The insert also contains one of the Polytechnic's earliest examples of the visual representation of Switzerland, whose promotion occupied five of the sixteen pages. The 13 images illustrated the main points of interest encountered en route, which were also highlighted in the text: the railway bridge in Kiel, that prospective tourists would have traversed; the "quaint nooks and corners" (PM, June 26, 1890, p. 411) and "interest and picturesqueness" (p. 408) of sites encountered in Lucenre, Brigue, Visp, Berne and Lausanne; the Rhine river, at Bale, that the tour planned on crossing on a ferry; the field of the battle of Waterloo; and "beautiful and wondrous works of nature" (p.411-412) such as a glacier, the Lake of Thun with the Alps in the background, and the waterfall and bridge near Zermatt (Figure 1). These images thus exemplify what was considered relevant to visit, in view of one's development, in this period: natural sceneries would have allowed one health-giving opportunities, and, as it was discussed elsewhere, to "return a wiser and better man or woman - wiser in mind, better in disposition, and with thoughts on a higher plane" (PM, November 1, 1899, p. 227); the study of the architectural and heritage sites encountered en route was seen as refining the taste of the participants; while the interest in old fashioned buildings demonstrates a sign of nostalgia for a rural past in the face of a growing urban modernity (Andrews, 1989). Furthermore, as exemplified by the illustration of the field of the battle of Waterloo (1815), which prospective tourists would have visited on the way home, images also reflected the view that travel offered the opportunity of visiting places of historical significance, in this instance furthering people's general understanding of Britain's relations with neighbouring countries. These illustrations certainly responded to a market demand for illustrated publications, and as the $P M$ noted elsewhere, prospective tourists would have been able to buy such "artistic souvenirs of the spots they visit" (PM 29 May 1891, p. 10). Yet they were also referred to as a source of further preparation: "I have given all the information needed for practical purposes" the editor added "but if any would like fuller descriptions they cannot do better than obtain [the guide]" (PM 29 May 1891, p. 10). The educational significance of these images was also reinforced by the fact that, in Regent Street, images from abroad were widely available to the Polytechnic's community, and contributed to normalising the idea of travel as an agent of change in its educational project. These included lantern lectures delivered by Polytechnic staff and guest-speakers such as explorers, war correspondents and missionaries; the cinematograph; the circulation of travel books and maps; and travel letters written by Hogg, the Polytechnic staff, and members of the Polytechnic community, regularly published in the $P M$. Through 
this, the Polytechnic sought to encourage its community to embrace one of the many forms of travel it promoted. This, in turn, sanctioned a particular use and understanding of visual images of travel. Accordingly, in the context of the tours these images were used not just to promote the destinations but also to contribute to the instruction (about what to see and how to see it) of prospective tourists.

Likely because of printing costs, the brochures printed in the second-half of the 1890s contain few images, though they began to reappear at the beginning of the new century. Their function was again that of prescribing the sites that a 'proper' tour ought to stop at, and how such sites ought to be looked at. This is suggested by the way in which, through the page layout, the images were made to endorse the routes described. In the Swiss section of the Polytechnic Holiday Guide of 1905, for example, the image of the Schollenen Gorge (figure 2) interrupted the text the moment the description of the excursion to the Furka and Grimsel Passes mentioned it, as to guide the reader through the image itself. Likewise, in the Polytechnic Swiss Tours of 1910 the photographs of the Reichenbach Falls, the Schollenen Gorge, the Rhone Glacier and the Grimsel Pass, just to name a few, equally complemented the text. The assessment that these images were chosen because they represented those iconic sights/sites that the PTA invested with formative value is supported by the consideration that, in the period between 1888 and 1923, the organisation consistently used exactly the same images, or very similar ones, across different promotional platforms. In the specific case of the Swiss tours, for example, of the eleven photographs used in the 1905 Polytechnic Holiday Tours brochure, ten were also used in the 1910 and two in the 1914 brochures, while others illustrated articles on the tours published in the $P M$, and printed as postcards. The use of the same images can also be observed in the repeating of photographs published in the brochures for 1910, 1914 and 1923, the editorials published in the PM, postcards, and in the guides to Lucerne published by the Polytechnic in 1908 and 1923. As the years progressed the PTA included new images, yet in terms of both subject and composition these were not dissimilar to previous ones: photographs of the Lion of Lucerne, the Axenstrasse, the railway ascending Mount Pilatus, Lake Lucerne, The Devil's Bridge, the summit of the Stanserhorn and the glacier in Chamonix, for example, infallibly return in the brochures produced throughout this period. If the use of the same negatives could have been a way to save money, the fact remains that when different images were printed they tended to be stylistically almost identical to previous ones; this indicates that the PTA purposefully chose a certain subject and aesthetic. 
To an extent, one function of these images was that of promoting the Swiss tours; in this sense they conform with what Urry has described as the emerging tourism industry's transformation of the picturesque into a style of representation reminiscent of an informed, and hence didactic, approach to the travel experience (1990, p. 129). However, the promotion of Switzerland must also be evaluated in relation to the Polytechnic's recognition of the relationship between travel and its role for a citizenship project, thus complicating their understanding simply as a marketing tool. As seen, in a context of 'rational recreation' the Polytechnic leaders felt the responsibility to teach tour participants - be it members, students or the general public - how to behave 'properly', seeking to develop tourists' identity in relation to that of the nation. This indicates that, even as an increasingly competitive market ultimately determined the nature of the tours, publicising travel as a formative experience to be undertaken as a duty of citizenship remained. The promotion of the tours continued, in this way, to support such an (ambitious) institutional view. The choice itself of the picturesque style can thus be understood, within this context, as a way to 'form' tourists as respectable citizens. The picturesque "taught tourists not only where to look but also how to sense the landscape, experience it" (Löfgren, 1999 , p. 12), thus allowing participants to demonstrate they could engage in a "meaningful relationship with visited places" (Buzard, 1993, p. 12). Following from the tradition of the Grand Tour, these images contributed to promote the aesthetic sensibility of a bourgeois 'ruling class', which was considered 'proper'. Indeed, the choices made in marketing the tours illustrates how, beyond publicising the destinations, the PTA was concerned during this time with instructing potential customers on what made travel 'worthy'. It did this by teaching tourists how to appreciate the world (in this instance visually) - thus aiming, above all, to teach them cultural respectability.

\section{HARNESSING CONSUMERS' DESIRES, 1924 - 1939}

In 1927, after a three-years absence from the PM's pages, the PTA published an advertisement for the tours to Switzerland: "to Europe's playground by Polytechnic!" (Figure 3) (June 1927, p. 124). This cartoon-style illustration offers a first example of a shift in how travelling abroad was now viewed. As the key stations tagged in the illustration suggest, the itinerary was largely the same, including for example Lucerne, Lugano, Grindelwald or Basle, while the inclusion of mountains, a lake, architectural sites and people climbing, suggests that the iconic sights/sites or activities considered worth pursuing had also not changed. However, this 
promotional representation no longer prescribed how each site ought to be approached; rather, it presented an 'abstracted' experience of visiting Switzerland. In doing so, the PTA proposed what one could have chosen to see and experience abroad. In the example here discussed, this was reinforced by the text that accompanied the advertisement, which called forth tourists by encouraging them to project themselves into the experiences proposed by the illustration:

A deep blue lake ... a brief fringe of sunlit beach ... then dark forests climbing halfway up to the snow-clad peaks which tower above them ... Switzerland ... Europe's Playground ... your summer holiday!

This year, experience the splendid change which only foreign travel gives. A change which sees your daily life and habits dropping away like a cloak, until you feel that this is your life. This enchanted wandering, this drinking in of beauty, this tasting of new and rare delights ... you were made for this. And when the time comes to return, you have so much of your holiday to bring away with you. Vivid impressions, rich memories, new dreams, all stored away to carry you through the winter. And remember, because you have been interested, others will find you interesting too ( $P M$, June 1927, p. 124).

What is key here is the filter of individual experience, and its emotional dimension, which made tourists protagonists. In this respect the focus on the social prospects of tourism - "because you have been interested, others will find you interesting too" points towards the benefits that travel was now expected to have for tourists as individuals, as opposed to the previous ambition of contributing to the formation of a collective citizenship. If this marks a continuity inasmuch as travel was still seen as adding to one's cultural capital, it also reveals a shift in how this was seen to further one's development: from the acquisition of those manners and values necessary to form one's national citizenry and imperial identity, to the certification of one's social status via the acquisition of a signifier of class. That is to say, travelling was now seen to strengthen one's social prospects, at this time defined more by one's income or profession that cultural capital per se (Gunn, 2005), by contributing to the affirmation of one's social class. Accordingly, and following a trend that generally defined the industry at this time, the PTA embraced leisure as an espoused motive for travelling, and began promoting its tours as constituting individual, and not collective, experience. This in turn shaped the understanding of how such benefits of travel could be acquired - thus how they came to be promoted: as the promotional material reveals, the PTA fostered a social idea of leisure and emotionally-based approach to travelling and to the appreciation of culture, implying that travelling could be made improving simply by having a good time. 
This shift also required a new approach to tourists, as the PTA no longer related to them as people who needed to be formed, but responded instead to what it thought tourists, as customers, wanted. Consequently, the function of marketing became that of harnessing consumer desire, prompting tourists to act as consumers. As Campbell contends, modern consumerism is defined not by the purchase or use of an item, but rather by "the imaginative pleasure-seeking to which the product image lends itself, real consumption being largely a result of this mentalistic hedonism" (1987, p. 118). That is, consumption operates at the level of imagination by triggering in the consumer the sensation of what it would be like, or what it would imply (for example in terms of social status), to consume the product. This was reflected in a transformed approach to the function of marketing, that is, to the idea of how a product - in this case travel - should be advertised (Holloway, 2004; Nevett, 1982; Ward, 1998). The modern meaning of advertising emerged at this time, as "the sense of informing becomes fully subordinate to that of persuasion" (Barnard, 1995, p. 30), thus focusing increasingly on the "symbolic" qualities of products (Leiss et al., 1986, p. 155). A number of studies have explored how, in order to harness consumers' desires, during this period numerous travel firms turned to artists to produce imaginative representations of their offer (see for example Williamson, 1998). At the PTA, the first step taken by Studd was to 'brand' the company's services: this took the form of the image of a flying seagull, usually accompanied by the slogan 'travel Polytechnic' (figures 3 and 4).

The function of promotional representations became that of anticipating an experience so that tourists could get a sense of how it would be like, for them, to travel to a given destination with the PTA. Destinations became a 'playground', their landmarks represented as a set of options for tourists to choose from in constructing their potential experiences abroad. The summer programmes for 1935 and 1938, for example, used the idea of the 'map' introduced with the 1927 advertisement to promote an idea of Switzerland as experiences, and tourists as customers ready to consume such leisure-based individual experience. In both instances the cartoonish map of Switzerland sketched the geographical position of the PTA facilities by locating them in the midst of stereotyped characters and historical figures (from local peasants to William Tell). While the 1937 programme (figure 5) represented Lucerne through images of a heritage-looking site; groups of (seemingly) tourists engaged in various activities; and, in the centre, a photograph of Studd himself, standing next to a group of (again, seemingly) tourists and pointing with his stick to the horizon - but also to the activities illustrated on the insert. As Studd himself reiterated in the text 
superimposed in figure 5: "In the champagne air of Switzerland, among the snowpeaks, you feel a new being, younger, more active, more intensely alive". The PTA put itself in the position of expertise and reliability, there to provide what was promoted as 'the best' service. Tourists were left with the task of enjoying the tours, tailoring them to their own tastes and interests. By evoking the sense of enjoyment and leisure that the travel firm recognised as a market demand, travel representations were thus expected to encourage tourists to see destinations as products for consumption. That is to say, to fulfil the experience of travel and realise themselves, tourists had to consume such options.

Analyses of the significance that travel had at the Polytechnic, and of how this was carried through by the PTA, have argued that the educational ambition of the early tours ultimately failed to provide a tool for the formation of modern citizens (Strong, 2012, p. 131). Yet, as Strong recognises, the history of the Polytechnic reveals how "the significance of travel in modern life was, and continues to be, more than the fulfilment of consumer desires as an individual right" (2012, p. 130). Our research has shown how such a statement can be extended to describe continuity in the aspirations of the PTA during the fifty years here considered. The PTA promotion of tourism certainly confirms the view of a progressive commodification of travel and culture as recreational activities, yet it also shows that the idea of leisure should not simply be considered as necessarily 'non-educational' as a result. As we have shown, the different representations of the Swiss tours can indeed be discussed as standing for two different approaches to travel itself as individual development. If the passage from institutional collectivism to an emphasis on individualism was the inevitable response to market forces, the organisation's persistent attempts at defining the tours in 'improving' terms also signals the ambition to adapt 'educational' goals to a new social, cultural and economic order. The educational legacy of the Polytechnic suggests that the function of leisure forms of cultural tourism was still, in a way, that of engaging with the improving benefits of travel. That is, it intended leisure to be developed as yet another way to engage with culture, now for the purpose of contributing to social formation in an increasingly commodified social context.

\section{CONCLUSION}

Examining the development of the PTA has allowed for reflection upon a transformation in the way in which late-nineteenth and early twentieth-century society came to understand the benefits of touring abroad and, conversely, the expected role 
of travel within society. This research thus makes an important contribution to the literature on the growth and development of tourism industry in Britain, and to the understanding of how its representation can be analysed in order to foster the study of tourism.

Firstly, the analysis of the PTA's case contributes to debates surrounding the commodification of culture as products of consumption. Specifically, it follows developments in the late nineteenth and early twentieth century which complicate what we could define, drawing from Campbell (1987), as the 'hedonistic turn' in tourism by proposing a discussion in terms of a transformed approach to the acquisition of an 'improving' experience. This was now based on the engagement with subjective emotions and personal interests. These are new terms in which the emergence of leisure tourism in the early twentieth century can be discussed and stands for one way to engage with an increasingly commodified cultural context. This complicates the 'hedonistic turn' by suggesting that this should be considered not as a devalued, or inauthentic, cultural experience, but as the negotiation with an emerging consumerist society. Recent studies on the contemporary commodification of museums and galleries as 'educative leisure' (Foley \& McPherson, 2000; Hanquinet \& Savage, 2012) have for example argued that this has developed as an attempt to offer more inclusive ways of engaging with culture (Hooper-Greenhill, 1999; McPherson, 2006). The case of the PTA indeed indicates that a preoccupation with how to mediate the effects of an increasingly commodified social context was part of the shaping of the tourism industry in Britain in the early twentieth century. Additionally, this enriches our understanding of cultural displays as a consumable experience, often considered to have caused the end, in the 1980s, of the dominant view that culture is the "exclusive preserve of an educated minority" (Dicks, 2003, p. 37) As seen, this can be situated as actually starting in the early twentieth century through a realignment of the travel experience as centred on the personal and emotional experience of the individual tourist.

Secondly, by focusing on the PTA's promotional representations of its tours this research has extended to visually-based archive holdings Tribe's call to the use of artworks in exploring tourism (2008). Through an analysis of archive material it has been possible to explore the changing attitudes towards travel - attitudes that are "beyond the reach of words" (Tribe, 2008, p. 941) - in relation to the PTA's selfperception. Indeed, this method has allowed us to identify those forces that played a key role in the development of ideas of travel, culture and learning from the late 
nineteenth century. In doing so we have also demonstrated that by applying the method suggested by Tribe to the specific historicity of archival data it is possible to explore, as Towner had urged, "more general concepts of society" (1988, p. 51).

The reflections that have emerged in relation to the PTA have a number of implications for further research. The educational context out of which the PTA emerged has brought into focus how the growth and development of British tourism in the early twentieth century was also linked to the attempt to adapt the expected benefits of travel to a changing, increasingly commodified, society. Further research is needed to explore in what ways non-commercially based travel firms responded to this challenge in the period that we have discussed, and to record the views of the consumers and traders who lived in the interwar period. Research is also needed to explore the contemporary currency of this framework, specifically in the context of today's spectacularisation of culture. This could contribute to the understanding of the role played by tourism in the constitution of often-conflicting national and global social identities.

\section{REFERENCES}

Adler, J. (1985). Youth on the road: reflections on the history of tramping. Annals of Tourism Research, 12(3), 335-354.

Adler, J. (1989). Origins of sightseeing. Annals of Tourism Research, 16, 7-29.

Adorno, T.W. ([1969] 1991). The culture industry: selected essays on mass culture. J.M. Bernstein (Ed.) London: Routledge.

Andrews, M. (1989). The search for the picturesque: landscape aesthetics and tourism in Britain, 1760-1800. Stanford, California: Stanford University Press.

Ateljevic, I., \& Doorne, S. (2003). Culture, economy and tourism commodities. Tourism Studies, 3(2), 123-141.

Bagnall, G. (1996). Consuming the past. In S. Edgell, K. Hetherington, \& A. Warde, (Eds.), Consumption matters: the production and experience of consumption (pp. 227-247). Oxford: Blackwell.

Bailey, P. (1978). Leisure and class in Victorian Britain: rational recreation and the contest for control. London: Routledge.

Barnard, M. (1995). Advertising: the rhetorical imperative. In C. Jenks (Ed.), Visual culture (pp. 26-41). London; New York: Routledge.

Barthes, R. (1977). The Photographic Message. In Heath, S. (Trans.)

Image/Music/Text (pp. 15-31). New York: Hill and Wang. 
Barton, S. (2005). Working class organisations and popular tourism, 1840-1970. Manchester: Manchester University Press.

Barton, S. (2008). Healthy living in the Alps: the origins of winter tourism in Switzerland, 1860-1914. Manchester: Manchester University Press.

Baywater, M. (1993). The market for cultural tourism in Europe. EIU Travel and Tourism Analyst, 6, 30-46.

Bennet, T. (1988). The exhibitionary complex. New Formations, 4, 73-102.

Borocz, J. (1992). Travel-capitalism: the structure of Europe and the advent of the tourist. Comparative Studies in Society and History, 34(4), (October), 708-741.

Bourdieu, P., (1984). Distinction: a social critique of the judgment of taste. London:

Routledge \& Kegan Paul.

Bourdieu, P., (1986). The forms of capital. In J. Richardson (Ed.), Handbook of theory and research for the sociology of education (pp. 241-258). New York: Greenwood.

Breathnach, T. (2006). Looking for the real me: locating the self in heritage tourism. Journal of Heritage Tourism, 1(2), 100-120.

Broomhall, S., Pitman, T., Majocha, E., \& McEwan, J. (2010). Articulating lifelong learning in tourism: dialogue between humanities scholars and travel providers. Canberra: Australian Learning and Teaching Council.

Burke, P. (1995). The invention of leisure in early modern Europe. Past \& Present, 146, 136-150.

Buzard, J. (1993). The beaten track: European tourism, literature, and the ways to culture, 1800-1918. Oxford: Clarendon Press.

Campbell, C. (1987). The romantic ethic and the spirit of modern consumerism. Oxford: Basil Blackwell.

Cordery, S. (1995). Friendly societies and the discourse of respectability in Britain, 1825-1875. Journal of British Studies, 34(1) (January), 35-58.

Craik, J. (1997). The cultural component of tourism. In C. Rojek \& J. Urry (Eds.), Touring cultures: transformations of travel and theory (pp. 113-136). London: Routledge.

Dent, K.S. (1975). Travel as education: the English landed classes in the Eighteenth century. Educational Studies. 1, 171-180.

Dicks, B. (2003). Culture on display: the production of contemporary visitability.

Maidenhead: Open University Press.

Dominici, S. (2014). The democratisation of photography and the promotion of tourism: the Polytechnic Touring Association, 1888-1939. Unpublished PhD Thesis. London: University of Westminster. 
Dominici, S. (2015). Tourist photographers and the promotion of travel: the Polytechnic Touring Association, 1888-1939. Photography and Culture, 8(3) (November), 1-27.

Falk, J.H., Ballantyne, R., Packer, J. \& Benckendorff, P. (2012). Travel and learning: a neglected tourism research area. Annals of Tourism Research, 39(2), 908-927.

Foley, M. \& McPherson, G. (2000). Museums as leisure. International Journal of Heritage Studies, 6(2), 161-174.

Franklin, A. (2007). The problem with tourism theory. In I. Ateljevic, A. Pritchard, \& N Morgan (Eds.), The critical turn in tourism studies: Innovative research methodologies (pp. 131-148). Amsterdam: Elsevier.

Fussell, P. (1980). Abroad: British literary traveling between the wars. Oxford: Oxford University Press.

Graves, R. \& Hodge, A., (1991). The long weekend: a social history of Great Britain 1918-1939. London: Cardinal.

Gunn, S. (2005). Translating Bourdieu: cultural capital and the English middle class in historical perspective. The British Journal of Sociology, 56(1), 49-64.

Hall, C. \& Rose, S. (Eds.) (2006). At home with the Empire: metropolitan culture and the imperial world. Cambridge: Cambridge University Press.

Hannam, K. \& Knox, D. (2005). Discourse Analysis in Tourism Research - A Critical Perspective. Tourism, Recreation, Research, 30, 23-30.

Hanquinet, L. \& Savage, M. (2012). 'Educative leisure' and the art museum. Museum and Society, (10)1, 42-59.

Heller, M. (2013). The Institute and the Polytechnic. In E. Penn (Ed.), Educating mind, body and spirit: the legacy of Quintin Hogg and the Polytechnic, 1864-1992 (pp. 45-77). Cambridge: Granta.

Hobsbawm, E.J., (1975). The age of capital. Abacus: London.

Holloway, J.C., (2004). Marketing for tourism. Harlow: Financial Times Prentice Hall. Home Tidings. See Polytechnic Magazine.

Hooper-Greenhill, E. (1999). Education, communication and interpretation: towards a critical pedagogy in museums. In E. Hooper-Greenhill (Ed.), The educational role of the museum (pp. 3-27). London \& New York: Routledge.

Huggins, M., \& Mangan, J.A. (Eds.) (2004). Disreputable pleasures: less virtuous Victorians at play. London: Frank Cass.

Inglis, F., (2000). The delicious history of the holiday. London: Routledge.

Jones, S.G. (1986). Workers at play: a social and economic history of leisure 19181939. London: Routledge \& Kegan Paul.

Lanfant, M.F. (1995). International tourism, internationalization and the challenge to 
identity. In M.F. Lanfant, J. Allcock \& E. Bruner (Eds.), International tourism: identity and change (pp. 24-43). London: Sage.

Leiss, W., Klines, S., \& Jhally, S. (1986). Social communication in advertising: persons, products and images of well-being. London: Methuen.

Löfgren, O. (1999). On holiday: a history of vacationing. Berkeley and Los Angeles: University of California Press.

MacCannell, D. (1976). The tourist: a new theory of the leisure class. New York: Schocken Books.

MacKenzie, J.M. (2001). The Victorian vision: inventing new Britain. London: V\&A Publications.

Matthews, N. (2013). From philanthropy to commerce: the rise and fall of the Polytechnic Touring Association. In E. Penn (Ed.), Educating mind, body and spirit: the legacy of Quintin Hogg and the Polytechnic, 1864-1992 (pp. 203-237). Cambridge: Granta.

McPherson, G. (2006). Public memories and private tastes: the shifting definitions of museums and visitors in the UK. Museum Management and Curatorship, 21(1), 4457.

Middleton, T.C., \& Lickoris, L.J. (2005). British tourism: the remarkable story of growth. London: Butterworth-Heinemann.

Morgan, M. (2001) National Identities and travel in Victorian Britain. Basingstoke: Palgrave.

Morgan, N., \& Pritchard, A. (1998). Tourism promotion and power: creating images, creating identities. Chichester: Wiley.

Musgrave, P.W. (1964). The definition of technical education: 1860-1910. Journal of vocational education \& training, 16(34), 105-11.

Nevett, T.R. (1982). Advertising in Britain: a history. London: Heinemann on behalf of the History of Advertising Trust.

Pimlott, J.A.R. (1947). The Englishman's holiday: a social history. London: Faber \& Faber.

Polytechnic Magazine. Issues from 1879 to 1965 of the in-house journal Home Tidings, renamed Polytechnic Magazine in 1888, are available online at http://westuni.websds.net.

Redfern, A. (1983). Crewe: leisure in a railway town. In J.K. Walton \& J. Walvin (Eds.), Leisure in Britain 1780-1939 (pp. 127-132). Manchester: Manchester University Press.

Richards, G. (1996). Production and consumption of European cultural tourism. Annals of Tourism Research, 23(2), 261-283. 
Ring, J. (2011). How the English made the Alps. London: Faber \& Faber.

Ritchie, B. W., Carr, N., \& Cooper, C. P. (2003). Managing educational tourism. Buffalo: Channel View Books.

Rojek, C. \& Urry, J. (Eds) (1997). Touring cultures: transformations of travel and theory. London: Routledge.

Sekula, A. (1986). The Body and the Archive. October, 39, 3-64.

Shennan, M. (1991). Teaching about Europe. London: Cassell Educational Limited.

Shepherd, R. (2002). Commodification, culture and tourism. Tourist Studies, 2(2), 183-201.

Simon, B. (1974). Studies in the history of education: Vol. 2. Education and the Labour movement, 1870-1920. Lawrence \& Wishart.

Snape, R. (2004). The Co-operative Holidays Association and the cultural formation of countryside leisure practice. Leisure Studies, 23(2), 143-158.

Strong, M.M. (2012). Class trips and the meaning of British citizenship: travel, educational reform, and the Regent Street Polytechnic at home and abroad, 18711903. Journal of British Studies, 51, 102-131.

Strong, M.M. (2014). Education, travel and the "civilisation" of the Victorian working classes. Basingstoke: Palgrave Macmillan.

Studd, R. (1950). The holiday story. London: Percival Marshall.

Syrjämaa, T., (2008). Selling history to tourists: advertising the past as a tourist attraction in early 20th century Italy. In A. Kostiainen \& T. Syrjämaa (Eds.), Touring the past: uses of history in tourism (pp. 41-57). The Finnish University Network for Tourism Studies (FUNTS).

Swinglehurst, E. (1982). Cook's Tours: the story of popular travel. Poole: Blandford Press.

Tagg, J. (1988). The Burden of Representation: Essays on Photographies and Histories. Amherst: University of Massachusetts Press.

Thompson, A. (2005). The Empire strikes back? The impact of Imperialism on Britain from the mid-Nineteenth century. Harlow: Pearson.

Thompson, F.M.L. (1988). The rise of respectable society: a social history of Victorian Britain 1830-1900. London: Fontana.

Thorne, S. (1999). Congregational missions and the making of an imperial culture in $19^{\text {th }}$ century England. Stanford, CA: Stanford University Press.

Towner, J. (1988). Approaches to tourism history. Annals of Tourism Research, 15(1), 47-62.

Towner, J., (1985). The Grand Tour: a key phase in the history of tourism. Annals of Tourism Research, 12, 293-333. 
Tribe, J. (2005). New tourism research. Tourism Recreation Research, 30(2), 5-8.

Tribe, J. (2006). The truth about tourism. Annals of Tourism Research, 33(2), 360381.

Tribe, J. (2008). The art of tourism. Annals of Tourism Research, 35(4), 924-944.

Urry, J. (1990). The tourist gaze: leisure travel in contemporary societies. London: Sage Publications.

Walsh, K. (1992). The representation of the past in the post-modern world. London: Routledge.

Walton, J.K. (2000) The British seaside: holidays and resorts in the twentieth century. Manchester: Manchester University Press.

Walton, J.K. (2009). Prospects in tourism history: evolution, state of play and future developments. Tourism Management, 30, 783-4

Walton, J.K., \& Walvin, J. (Eds.) (1983). Leisure in Britain 1780-1939. Manchester: Manchester University Press.

Walvin, J. (1978). Beside the seaside: a social history of the popular seaside holiday. London: Allen Lane.

Ward, S. (1998). Selling places: the marketing and promotion of town and cities, 1850-2000. London: E \& F Spon.

Watson, L. (2003). Lifelong learning in Australia. Canberra: Department of Education, Science and Training.

Watson, G. L. \& Kopachevsky, J. P. (1994). Interpretations of tourism as commodity. Annals of Tourism Research, 21(3), 643-660.

Werry, M. (2008). Pedagogy of/as/and tourism: or, shameful lessons. Review of Education, Pedagogy \& Cultural Studies, 30(1), 29.

Williamson, A. (1998). The Golden Age of travel: the romantic years of tourism in images from the Thomas Cook Archives. Peterborough: Thomas Cook Publishing. Wood, E. (1934). Robert Mitchell: A Life of Service. London: Frederick Muller Ltd. 